\title{
تجربة الجامعة الإسلامية العالمية بماليزيا في تدريس مادة التفكير الإبداعي
}

\section{جمال أممد بادي*}

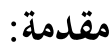

برزت أهمية التفكير بأنماطه المختلفة، ودوره الأساسي المحوري في عمليتي التعلّم والتعليم، في ظل تداعيات نتائج البحوث المتتابعة في علم النفس المعرفي على مدى العقود الثلاثة الماضية. وقدكان الجمل في بداية الأمر بين طائفتين من العلماء حول إمكانية تدريس التفكير. فهل يمكن تدريس التفكير؟ وهل يمكن نقله إلى الآخرين؟ وهل يمكن لجهود تطوير التفكير وتحسينه أن تنتج نتائج مثمرة مستمرة؟ أليس الكل يبذل جهداً والكل يفكر، واختبارات الذكاء أليست قائمة؟ كل هذه الأسئلة كانت مطروحة للنقاش وعرضة لاختلاف وجهات النظر في العقود الماضية.

ويقدم نكرسون بركنز أنموذجاً لرأي القائلين بجدوى تدريس التفكير بقوله: "إذا كان تدريس التفكير لا يمكن القيام به، ونحاول القيام به، فيمكن أن تضيع بعض أوقاتنا وجهودنا. ولكن إذا كان تدريس التفكير ممكنا ،

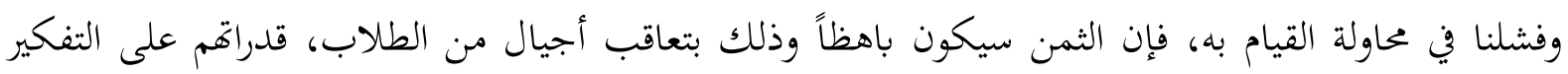
الفعال أقل بكثير مما يمكن أن يكون. وبناءً على ذلك فإن النصح الأنفع أن نتبنى الابحاه القائل بإمكانية تدريس التفكير، ولنحاول جادين وبقوة أن ندرسه، ولندع التجربة تثبت خطأنا إن كان لما ذلك." ومن الناحية العملية طوّر أهل التخصص في المجال المذكور، برامج تربوية وتعليمية جديدة تعتمد تدريس التفكير بأنماطه المختلفة، وخاصة التفكير الإبداعي منها، كمهارات وتقنيات أثبتت جدارتما، وأظهرت تأثيرها بشكل إيجابي على مستوى الأداء العلمي والأكاديمي، لدى الطلاب الذين وجدوا حظاً في دراسة تلك المهارات.

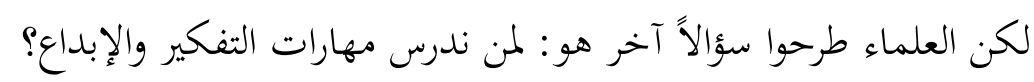
كانت العناية في بدايات القرن العشرين بالمتفوقين عقلياً والموهوبين، وفي أواخر منتصف القرن نفسه بدأت العناية - في كثير من الدول الغربية- تتجه إلى الطلاب كافة وإلى مستويات التعليم جميعها؛ بما فيها الحضانة والابتدائية دون نظر إلى مستوى تفوقهم. وقد أثتبت التجارب نجاح الفكرة وقد خصصت محاور المؤتمر العالمي الثامن للتفكير -الذي عقد في سنغافورة في 1997م- لدمج التفكير الإبداعي في المناهج التعليمية، كما عرضت دول عدة منها: أمريكا، وبريطانيا، وأستراليا، وفنزويلا، وسنغافورة بتحاربها، التي تجاوزت في بعضها خمسة بإِية عشر عاماً في ذلك الوقت.

* أستاذ مشارك بقسم الدراسات العامة بالجامعة الإسلامية العالمية بماليزيا سابقاً وبقسم الدراسات الإسلامية بجامعة السابع من أكتوبر بعصراته لييا حالياً. jmbadi@hotmail.com

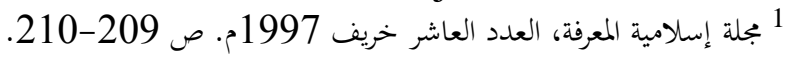

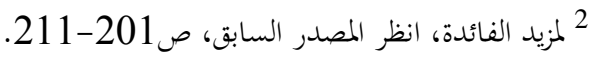


أولاً: الحطوات العملية الأولى التي اتخذةا إدارة الجامعة للبدء في تدريس مهارات الإبداع ضمن المقررات العلمية الجامعية:

يمكن تلخيص الخطوات التي التخذّا الجمامعة الإسلامية العالمية بماليزيا في تدريس المقرر على النحو الآتي:

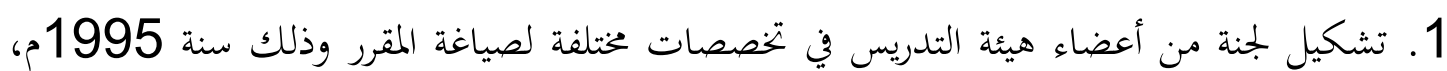

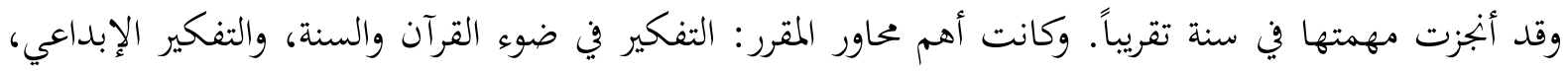

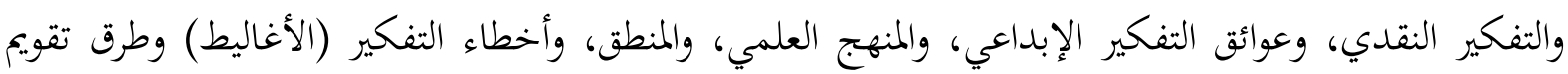
الأدلة، والجموعات، والاحتمالات، واتخاذ القرار، واللغة والتفكير.

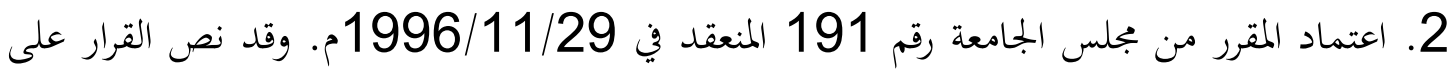

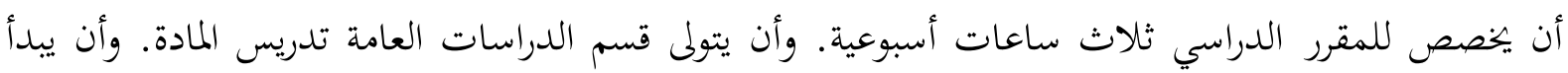

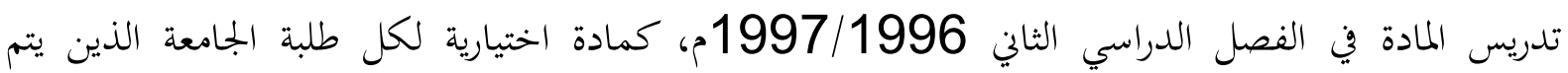

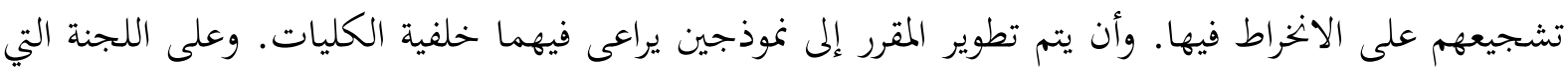

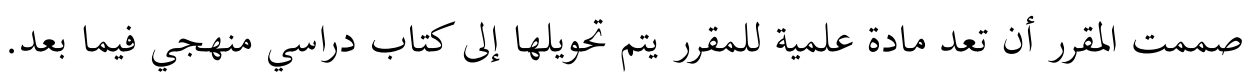

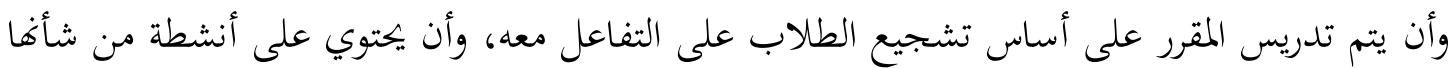

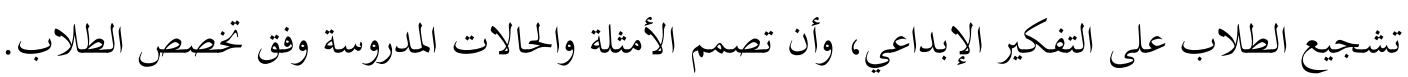

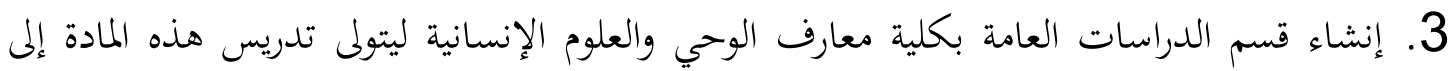
جانب مواد أخرى من المتطلبات العامة.

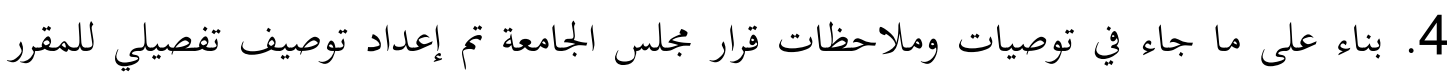

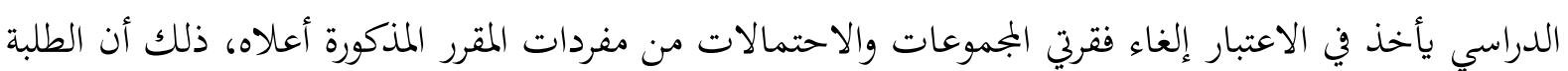
الذين طبقت عليهم المادة كانوا من طلاب كلية معارف الوحي والعلوم الإنسانية الذين تنفصهم الملنفية الرياضية.

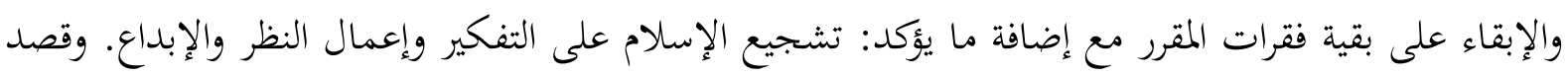

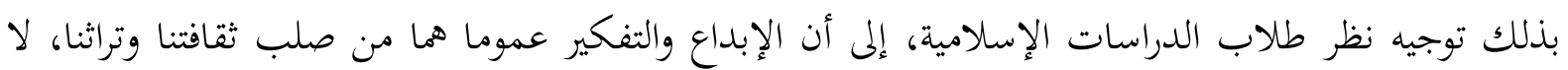

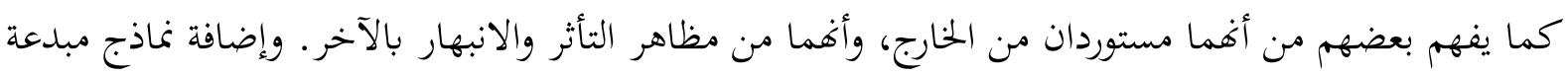

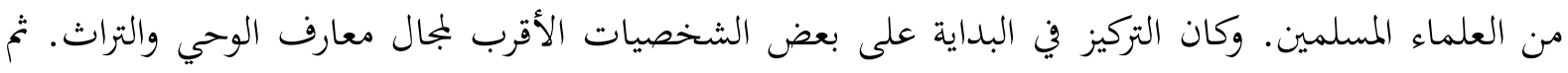

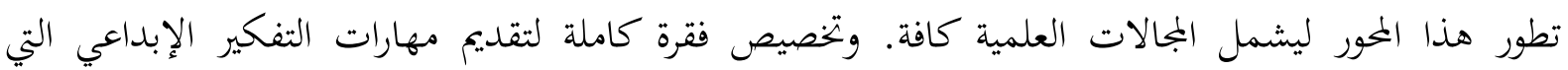
صمهها إدوارد دي بونو في كتابه "الإبداع الجاد".

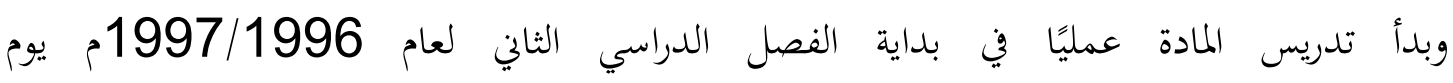

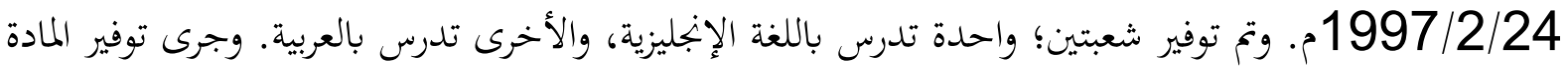

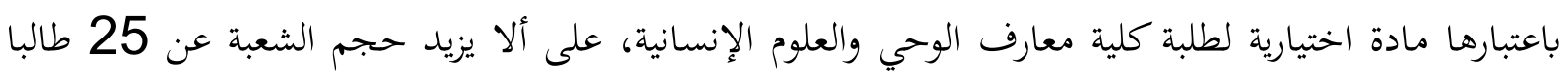

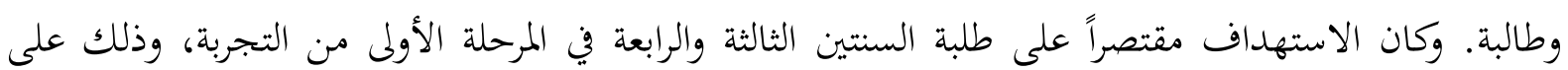


مدى فصلين دراسيين. ثم بدأ قسم الدراسات العامة في الفصل الدراسي الثاني 1998/1997م وحتى الفصل

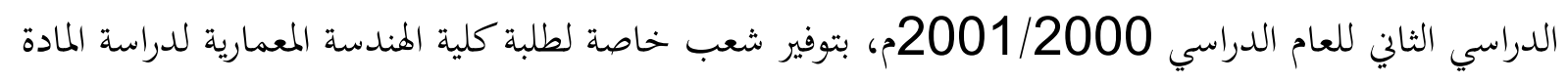

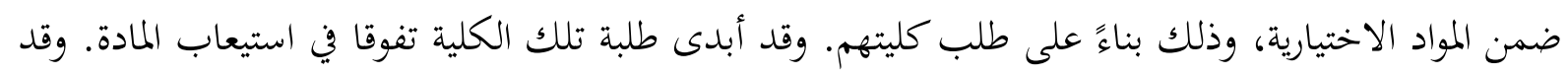

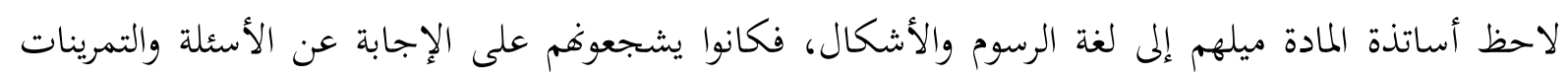
والتدريبات باستعمال تلك اللغة.

5. قرر مجلس الجامعة في اجتماعه 253 في 2001/2/23م أن تصبح مادة التفكير الإبداعي

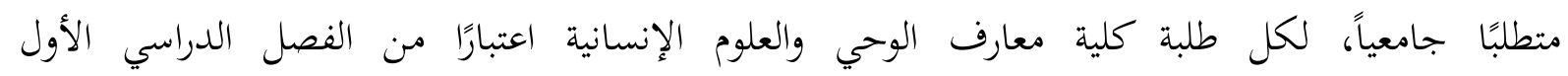

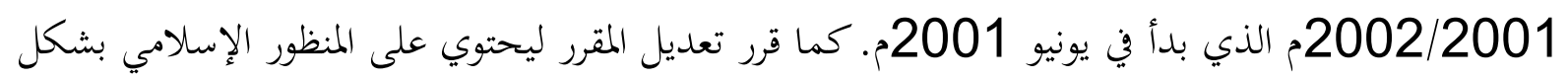

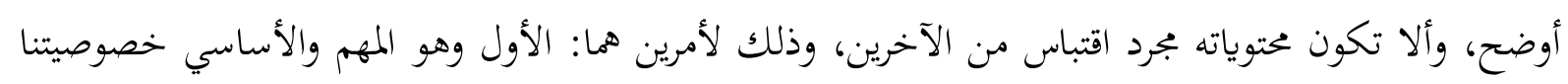

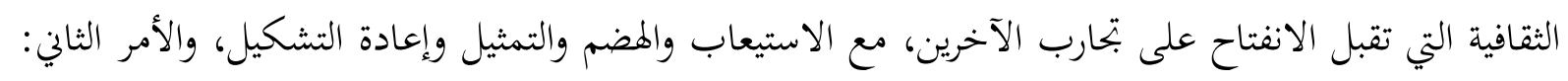

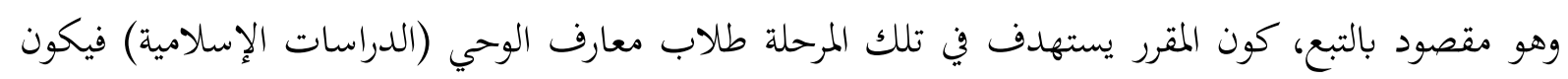

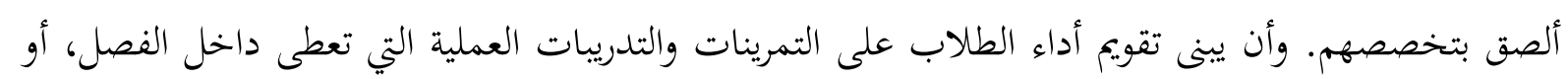

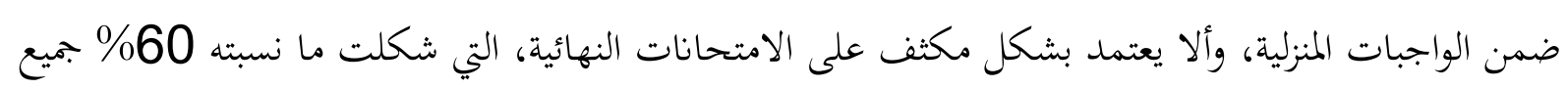

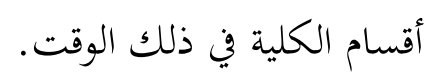

وتمشياً مع قرار مجلس الجامعة تم تعديل توصيف المقرر لتضم محتوياته الرئيسة، على النحو الآتي: تعريف

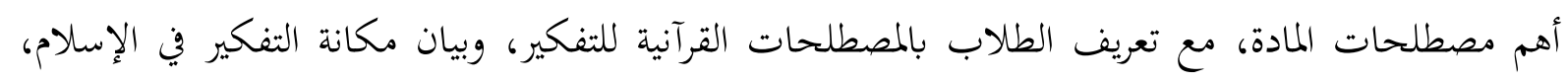

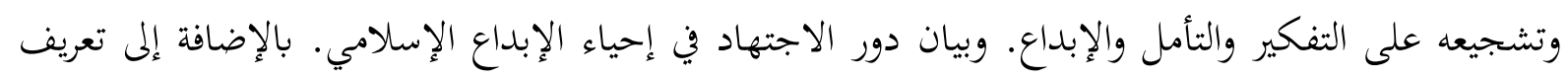

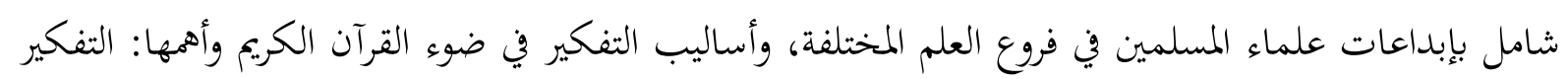

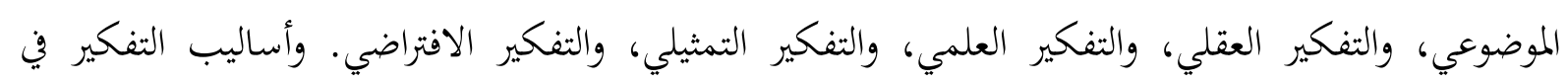

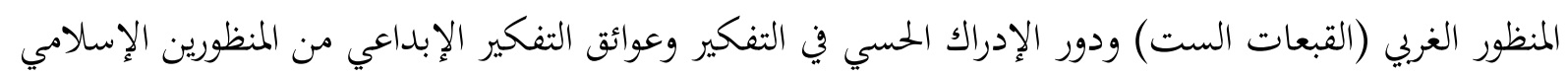

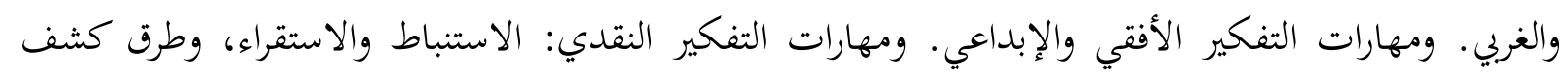

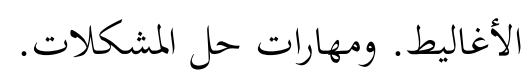

6. تمت مراجعة المقرر مرات كان أهمها في سبتمبر 2002م، ثم في يونيو 2003، وأخيراً في

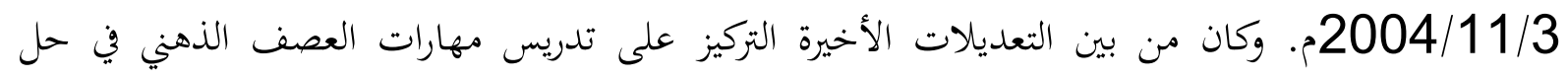

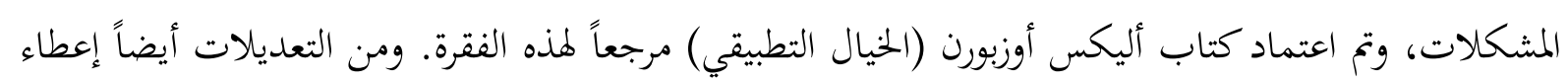

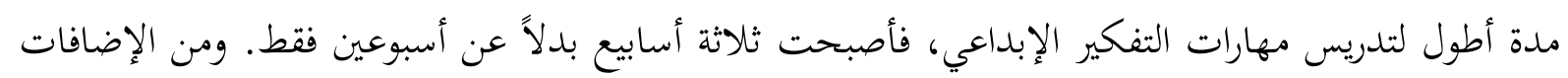

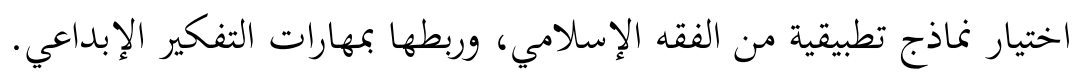


ثانياً: تقويم أداء الطلاب ومنهج تدريس المقرر:

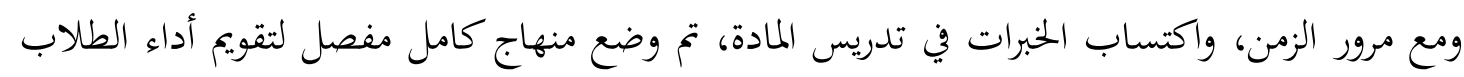

أثناء الفصل الدراسي على الشكل الآتي:

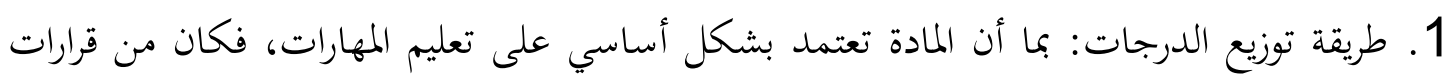

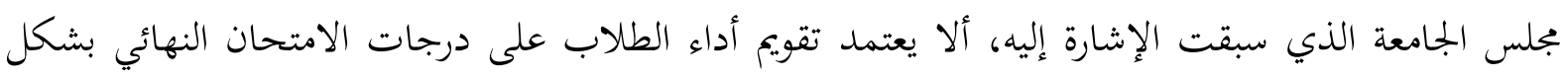

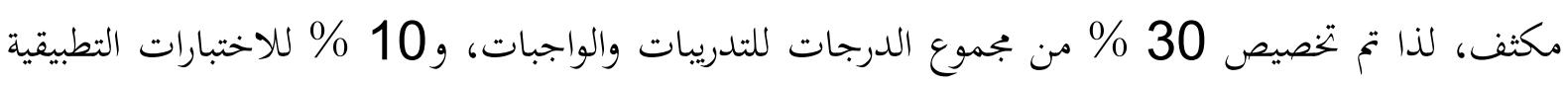

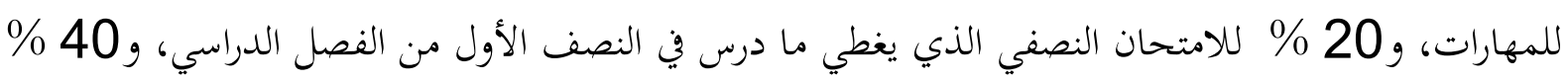
للامتحان النهائي.

2. الواجبات خارج الفصل: يعطى الطلاب في بداية الفصل الدراسي تعليمات مفصلة عن الواجبات

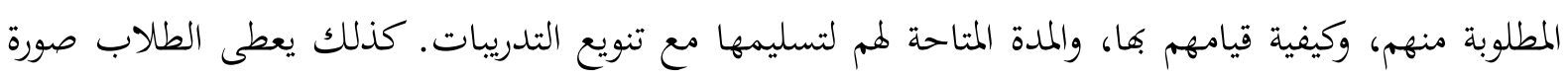

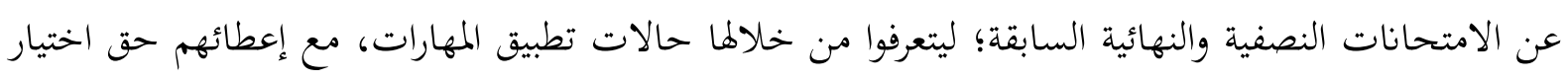
الحالات.

3. التعامل مع الطلاب الذين لديهم ضعف أو قصور في فهم المهارات أو استعمالها: فبعد تصحيح

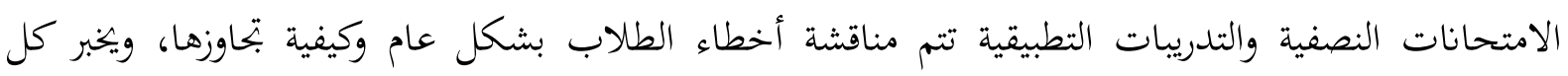

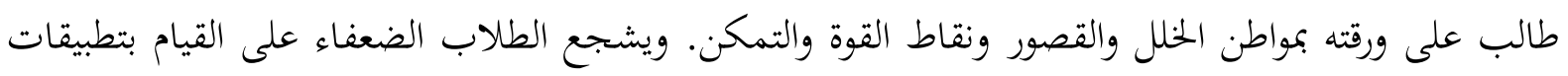

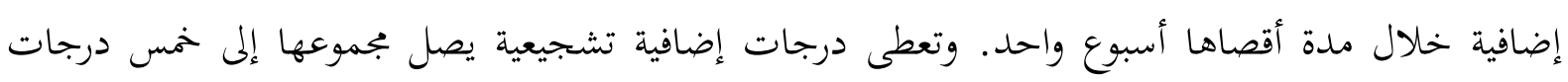
للطلاب الذين يلاحظ الأستاذ تحسناً في أدائهم.

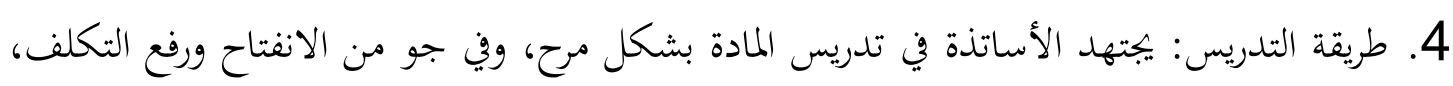

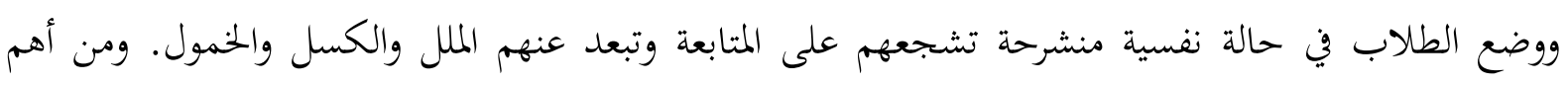

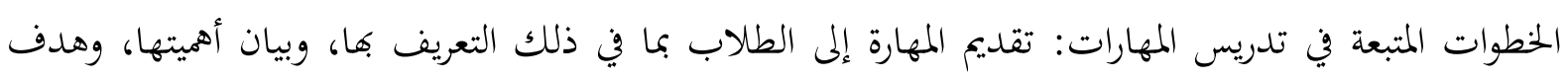

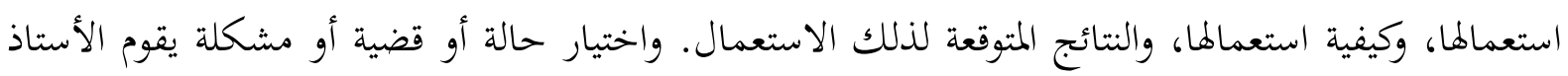

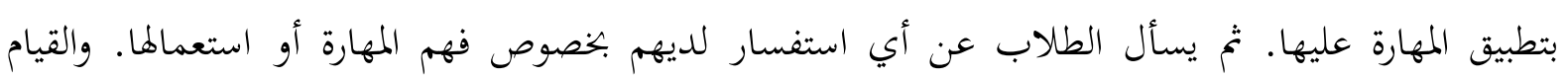

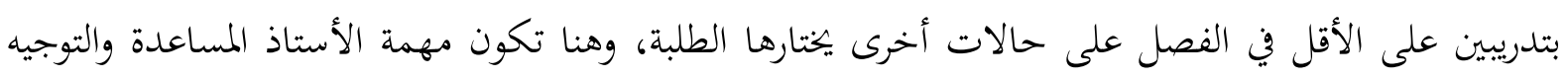

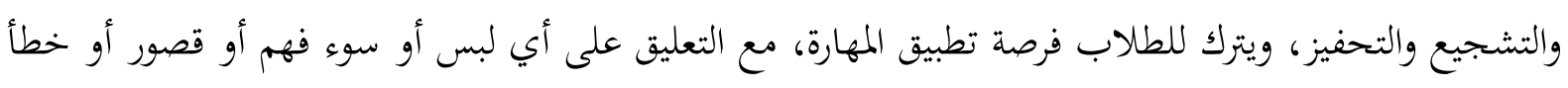

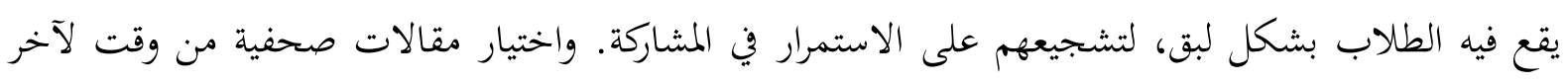

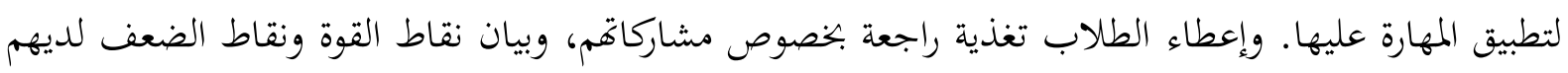

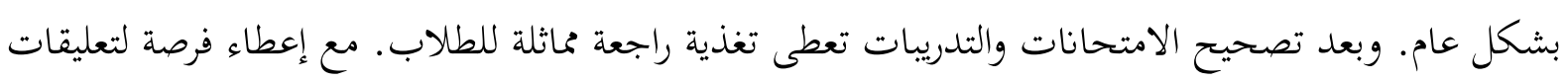

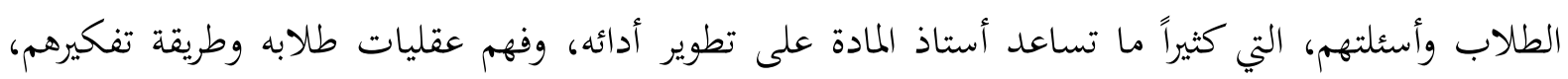

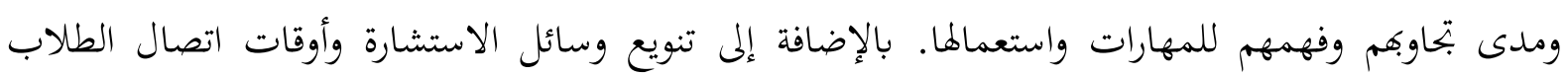


بأستاذ المادة، وأهمها: آخر خمس عشرة دقيقة من الدرس، وساعة مكتبية كل يوم من أيام الأسبوع، والاستشارة عبر هاتف المكتب الذي يوفر رقمه مع جدول الاستشارة للطلاب في بداية الفصل الدراسي. والاستشارة عبر البريد الالكتروني.

5. المادة العلمية للمقرر: حيث تم إعداد كتاب منهجي دراسي (باللغة الإنجليزية)3 يغطي ما يقارب 80\% من المقرر الدراسي، مع إعداد ملخصات في شكل نصوص أو عروض تقديمية، لكل المهارات وموضوعات المادة، تظهر من خلال صفحة الجامعة الخاصة بالتعليم الإلكتروين عبر مواقع الشبكة الدولية الانترنت.

\section{ثالثا: بعض العقبات4 التي واجهت الأساتذة في تدريس المقرر وكيف تم التغلب عليها:} 1. من أولى العقبات التي واجهت الأساتذة في تدريس المادة إثارة الطلاب وتشجيعهم وتحفيزهم؛ ليصبح الإبداع عنصراً مهما في حياهم اليومية، فيهتموا بتحسين تفكيرهم وتطويره حتى وإن كان جيداً في نظرهم. وهي مشكلة أشارت بكوث علم النفس المعرفي إلى أها نابتحة عن: "دعم وإعلاء الأفكار الخاصة

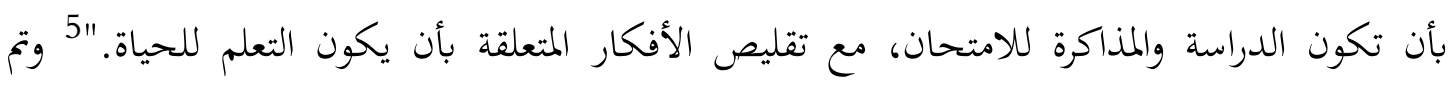
التعاطي مع هذه العقبة ببيان أهمية الإبداع ودوره في الحياة، ومدى حاجتنا إليه لحل مشكلاتنا وتطوير برابجنا وشؤوننا، ودخوله في كل جانب من جوانب الحياة. مع إعطاء أمثلة نموذجية لما نقره من هذه المسائل. وعادة ما يتم هذا في الأسبوع الأول وخلال اللقاءات الأولى مع الطلاب. 6 2. تنوّع طرق تفكير الطلاب ونوعية اللغة المفضلة لديهم: إن تدريس طلاب من كليات مختلفة أو تخصصات مختلفة في الكلية الواحدة، يعد أمرا في غاية الأهمية والحساسية. فاختلاف الخلفيات والتجارب والخبرات التعليمية ونوعية اللغة المستعملة أمر حساس جداً، ينبغي لمن يدرس هذه المادة أن يتفطن له ويتعامل معه بشكل منهجي. فقد لاحظ الأساتذة من خلال تدريس المادة تسع سنوات لطلاب كليات مختلفة وتخصصات متنوعة، أن كل طائفة منهم لما لغة مفضلة. ففي حين يفضل طلاب معارف الوحي وكثير من طلاب العلوم الإنسانية لغة الخطاب والكلام، فإن طلاب المعمار يفضلون لغة الأرقام والرسوم

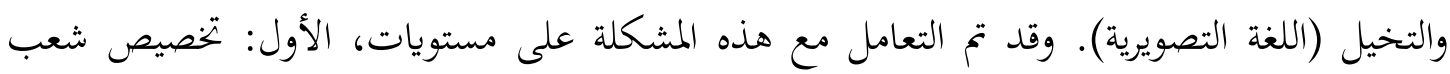

${ }^{3}$ Tajdin, Mustapha \& Badi, Jamal: Creative Thinking: an Islamic Perspective, (2004), IIUM Research Centre. Kuala Lumpur.

4 يمكن الإفادة مـن كتاب: التفكير مهاراته واستراتيجيات تدريسه للدكتور حسني عبد الباري عصر، [د.ت]، الإسكندرية: مركز الإسكندرية

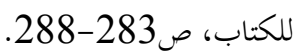

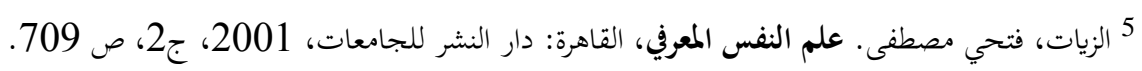

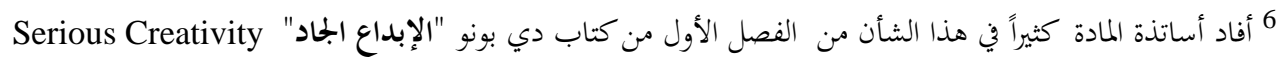


مستقلة لطلاب كل كلية ليصبح التعامل معهم بشكل أفضل. والثاني: معاملة كل طلاب حسب خلفياقم ولغاتم المفضلة، مع إكسابهم اللغات الأخرى وتشجيعهم على استعمالها. ومما لاحظه الأساتذة من فروق بين الطلاب، تميزّ أداء طلاب كلية المعمار عن طلاب التخصصات الأدبية. وهو أمر قررته بحوث علم النفس المعرفي المعاصرة. فيقول الدكتور فتحي الزيات: "إن صعوبات التعلم بأنماطها المختلفة، تميل إلى أن تشيع لدى التخصصات الأدبية، بصورة تفوق شيوعها لدى التخصصات العلمية." 3. لاحظ أساتذة المقرر بأن طلاب العلوم الاجتماعية والإنسانية أفضل أداءً من طلاب معارف الوحي في الجملة والعموم، وإن وجدت نماذج متميزة من طلاب معارف الوحي كأفراد. 8 ولعل أهم الأسباب وراء هذه الظاهرة عائق اللغة، إذ إن المادة تدرس باللغة الإنجليزية فقط دون العربية، وكثير من هؤلاء الطلاب الذين نتحدث عنهم (معارف الوحي) كانت دراساةم السابقة باللغة العربية يستوي في ذلك الطلاب المحليون والوافدون. مع التنويه هنا إلى أن الجامعة تطالب جميع طلابها بإجادة اللغتين العربية والإنجليزية، وتقوم بامتحافم قبل بدء دراستهم في الكليات التي اختاروها، وتطلب ممن لم يتجاوز تلك الامتحانات دراسة مواد إضافية في اللغة الإنجليزية، خاصة في مهارات القراءة والكتابة والاستماع، قبل التحاقهم بكلياتم، وقبل تسجيل مواد دراستهم المطلوبة. وهنا يبرز عائق متفرع عن سابقه ألا وهو: أن معظم الطلاب الذين يدرسون مادة التفكير الإبداعي في السنوات القليلة الماضية أصبحوا من المراحل الجامعية الأولى والثانية. وقد تم التعامل مع هذا العائق بتوفير مذكرات في المقرر الدراسي باللغة العربية لمن يحتاجها، وذلك بالإعلان في أوائل الفصل الدراسي عن هذا الأمر، وبعد سؤال الطلاب مباشرة عمن لديه هذا العائق. كذلك تم تخصيص ساعات الاتصال بالطلاب في المكتب (ساعة كل يوم) لشرح ما يجتاجه هؤلاء الطلاب لمن -رغب منهم- باللغة العربية. وقد سمح بعض أساتذة المادة لهؤلاء الطلاب بكتابة واجباهم، وتدريباهم وتمريناةم وإجاباتم عن أسئلة الامتحانات باللغة العربية. وفي العموم فإن نسبة هؤلاء الطلاب لا تتجاوز خمسة إلى عشرة بالمائة. وعائق انعدام أو قلّة الخلفية اللازمة للمقرر من علم النفس المعرفي. وقد تم التعامل مع هذا العائق بتوفير مادة علمية إضافية، أو إرشاد الطلاب إليها حال السؤال عن تفصيلات موضوع ما في مراجع هذا الفن المتوافرة. كذلك قام أساتذة المادة بتوفير ملخصات مفيدة في بعض هذه الموضوعات لهؤلاء الطلاب، وخاصة في السنتين الأخيرتين، بعد ظهور المشكلة بشكل ملحوظ.

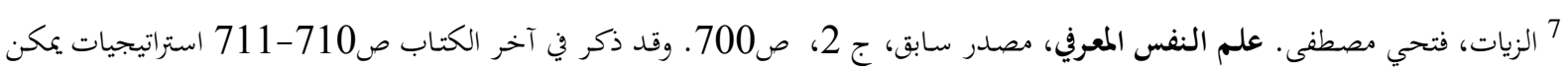
لأساتذة المادة الإفادة منها في التعامل مع ذوي صعوبات التعلم الثعلم من طلاب الجامعة.

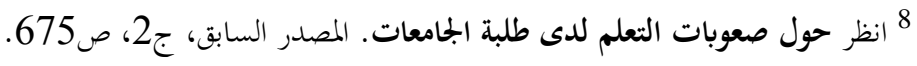


4. ومن العوائق التي قابلت الأساتذة في تدريس المادة، عدم مشاركة كل الطلاب في تطبيقات وتدريبات 4المهارات داخل الفصل؛ لكبر حجمه (خمسون طالباً وطالبة). ومن طرق التغلب علئ عليها إنجراء التدريبات

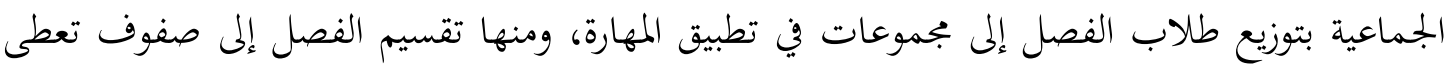

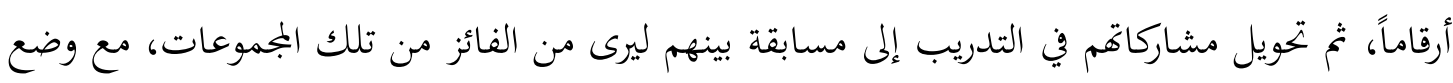

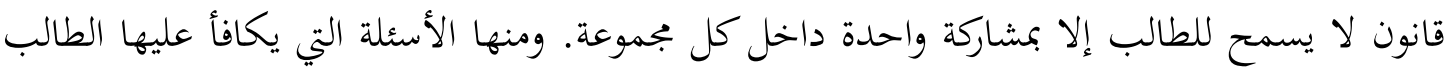

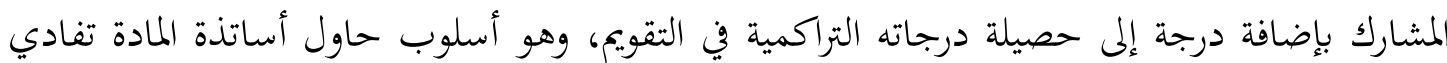
الإكثار منه حتى لا يتحول إلى شرط منعكس.

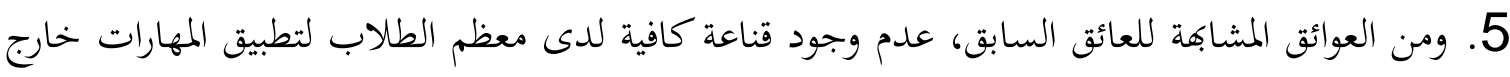

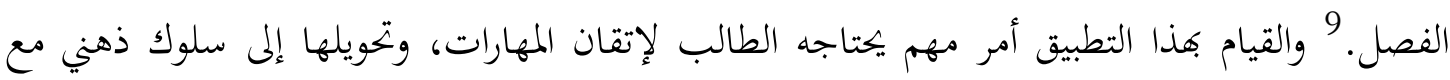

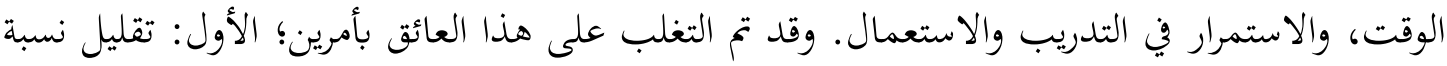

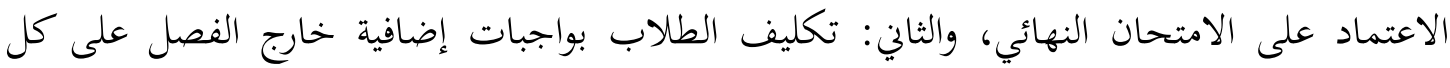

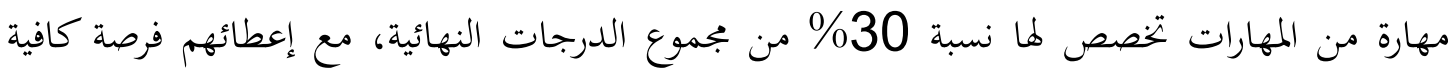

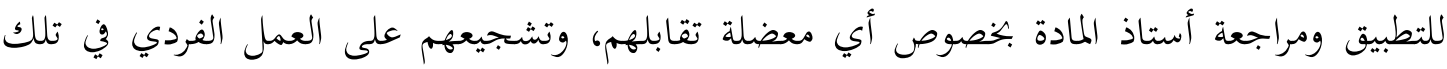

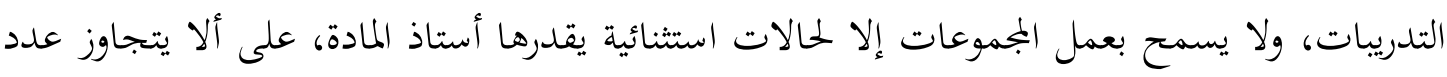
أفراد المجموعة ثلاثة طلبة. 6. ومن العوائق أيضا أن تعلُّم بعض مهارات الإبداع وتطبيقها أسهل من بعضها الآخر. فمن المهارات

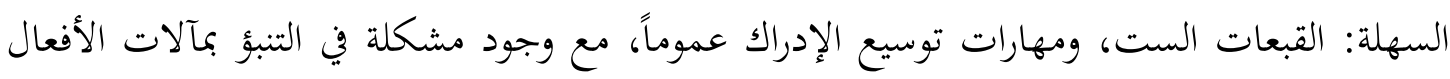

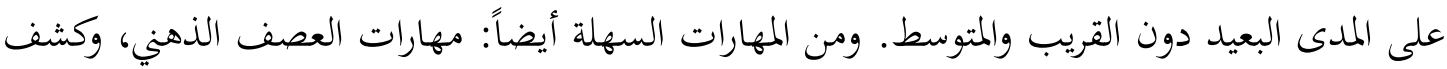

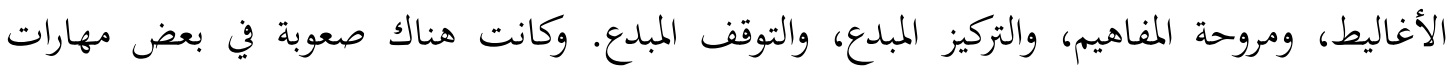

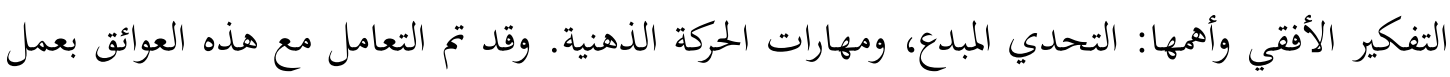
شرح وافٍ، وتطبيقات لمهارة التحدي المبدع، مع التركيز على جانبين من جوانب التحدي المهات المبدع هما:

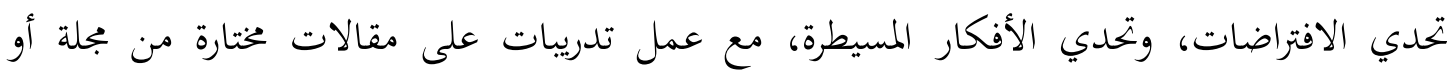

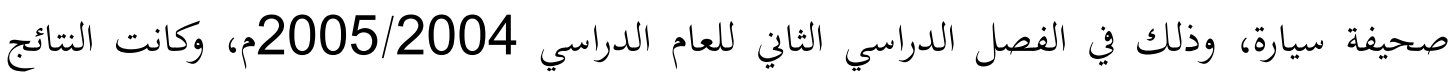
مشجعة. أما ما يتعلق بمهارات الحركة الذهنية، فقد تم التعامل معها بإضافة وقت أطول لتدريسها،

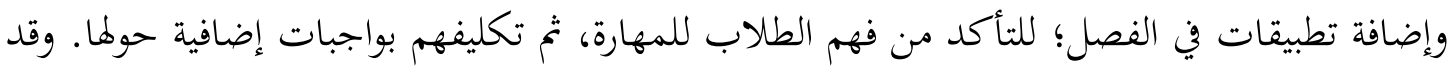

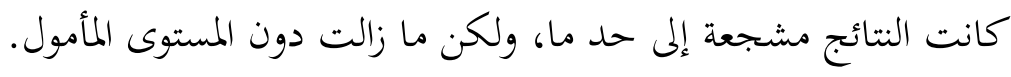

9 
7. ومن العوائق في تدريس مهارات الإبداع، ما قد يقع في تدريس أي مادة أخرى، ومن أمثلته هنا عائق

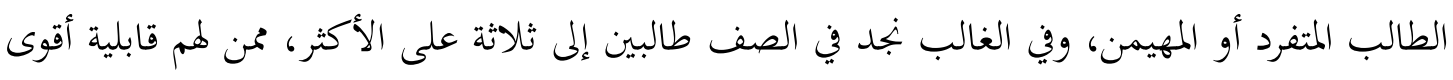

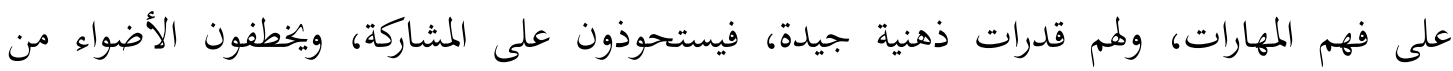

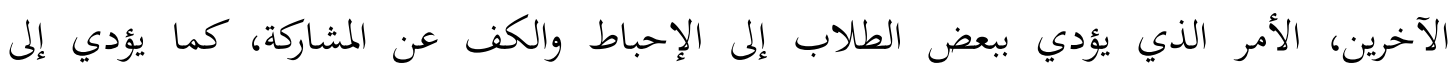

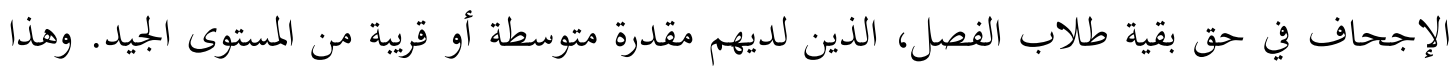

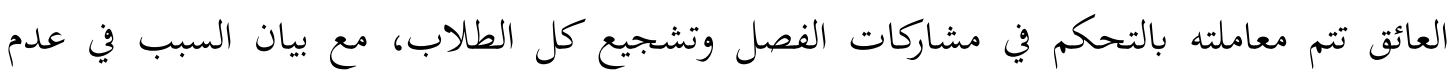

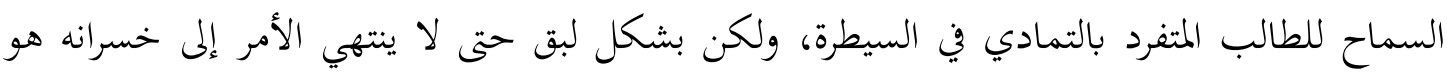

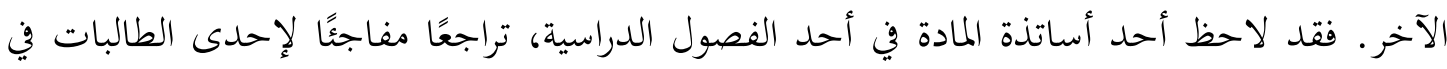

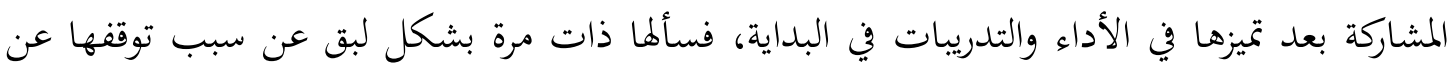

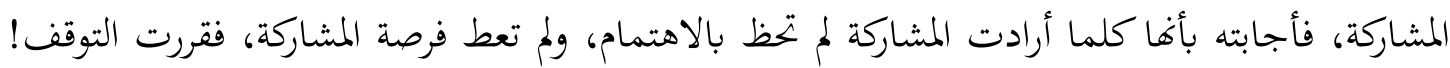

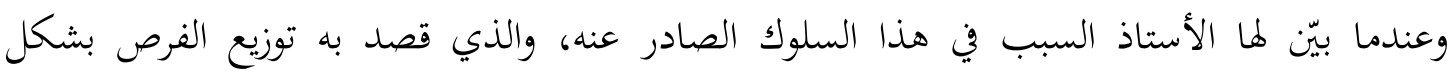
متكافئ لكافة الطلاب فهمت السبب ورجعت للمشاركة. 8. وهناك عائقان يتعلقان بتدريس المهارات، لمما علاقة بأستاذ المادة، وهما: أن يتحول المضمون والمشكلة الماتهل

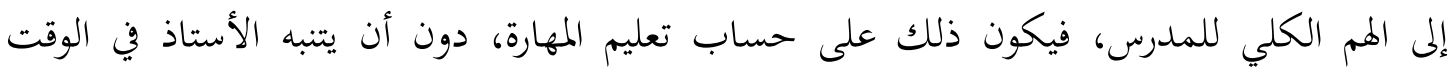

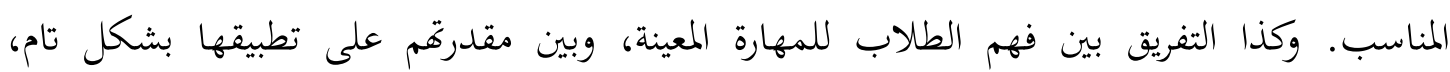

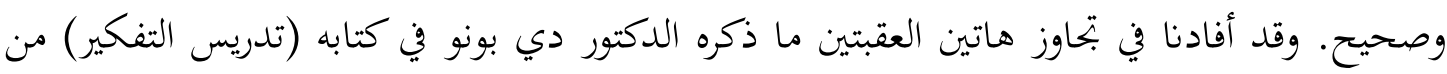
شرح مطول وموسع حول الموضوع. 10

\section{رابعاً: إنكالات حول تدريس الإبداع ومناقشتها:}

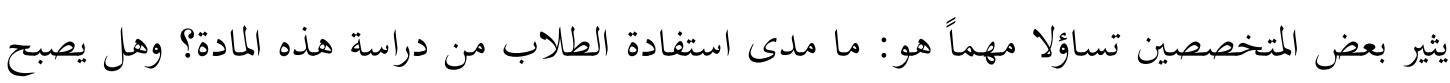
هؤلاء الطلاب مبدعين بدراستها؟ ويمكن الإجابة عن هذه التساؤلات من خلال المحاور الآتية:

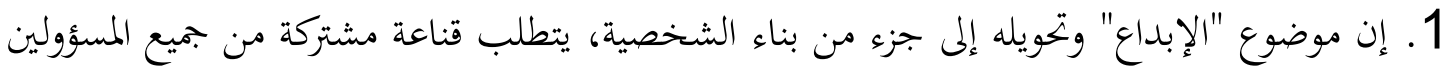

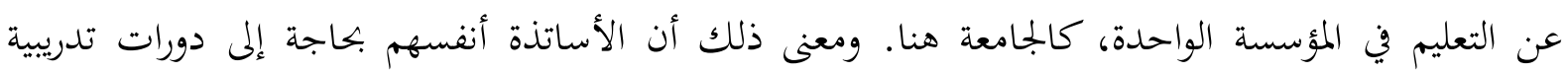
متواصلة في مهارات الإبداع، وتأهيلهم ليصبحوا قادين على نقل تلك المهارات إلى فصولهم الدراسية وطريقة

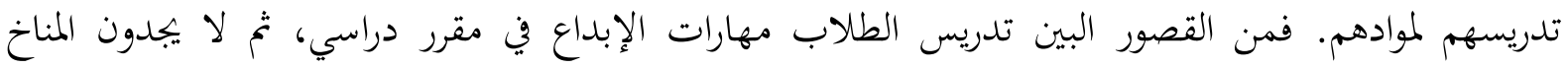

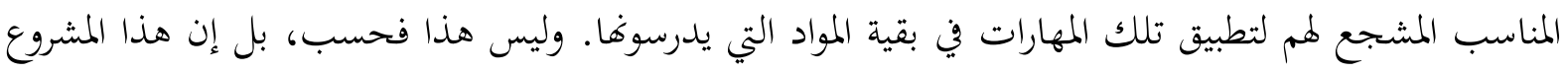

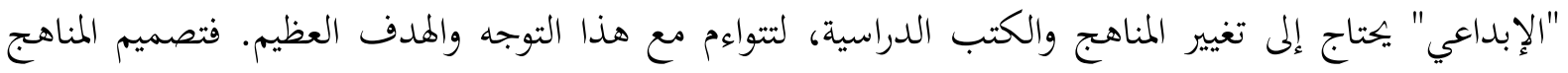

De Bono, Edward. Teaching Thinking, (1976), Penguin Books. ${ }^{10}$ 
والكتب التي لدينا لم يتم ضمن أهداف إنتاج طلاب مبدعين. وهذا ينعكس على طريقة ترتيب معلومات

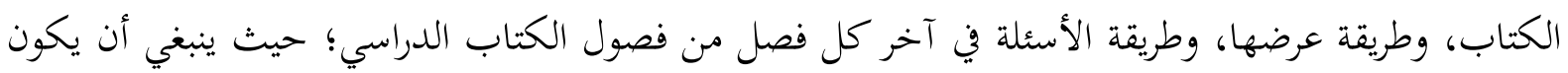

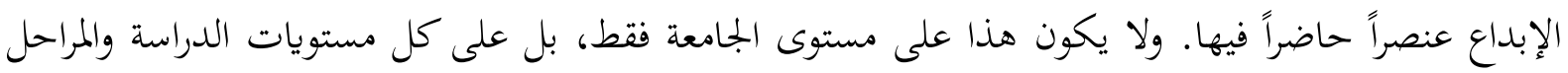
التعليمية بدءاً بالحضانة والمرحلة الابتدائية. فالطالب عندما يصل إلى الجامعة تكون عقليته قد تشكلت وشخصيته قد أخذت أبعادها.

وما ذكرته آنفا من متطلبات على مستوى التعليم، تؤكده الدراسات المعرفية المعاصرة؛ حيث تشير

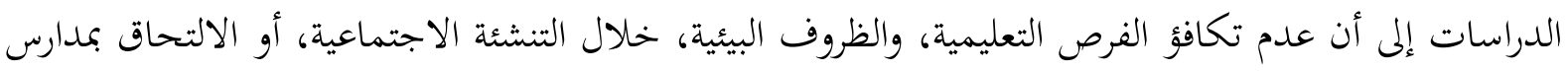

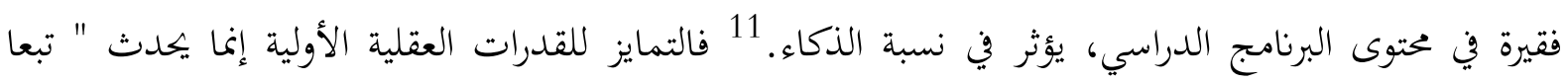

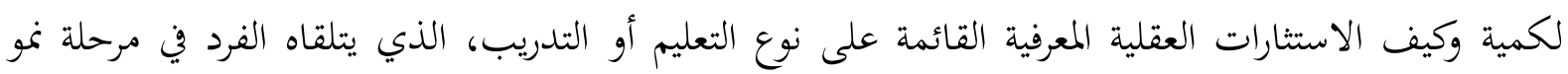
تلك القدرات." تمبية وكيف فإذا كان التعليم في مستوياته الدنيا متدنيًا، وإذا كانت شخصية الطالب مبنية ومؤسسة على الحفظ

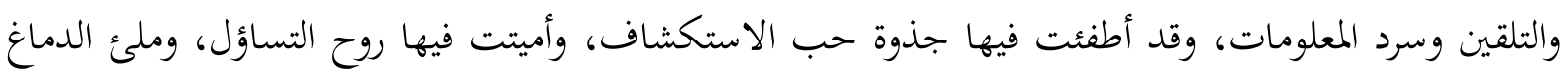

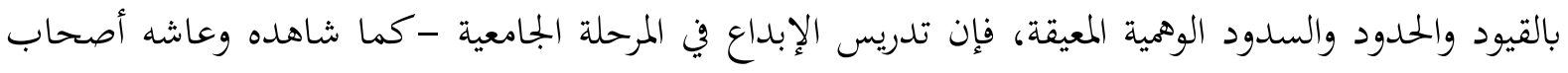

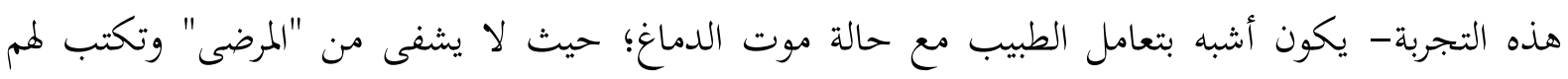

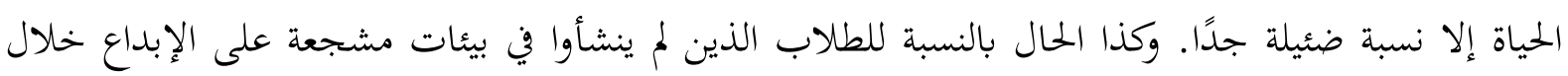

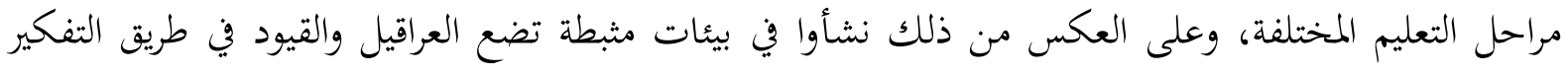

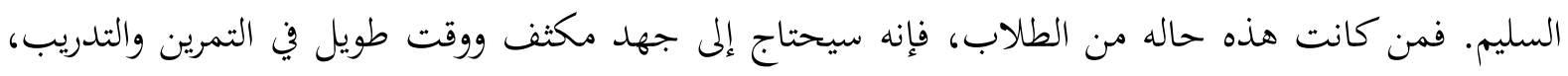
حتى يتمكن من تغيير سلوكياته الذهنية الجامدة. وأريد هنا عرض نموذج واحد لما ذكرته آنفا حول أثر أساتذة المقررات الدراسية في غرس الإبداع لدى لئه

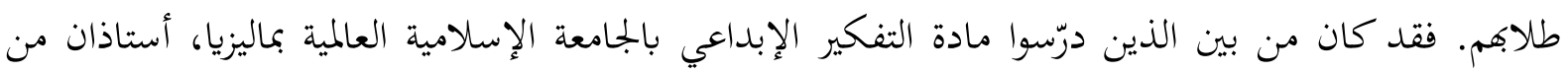

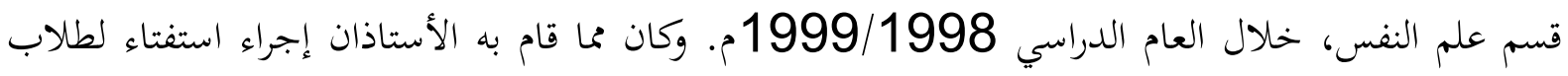

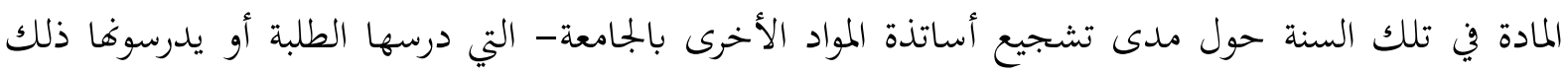

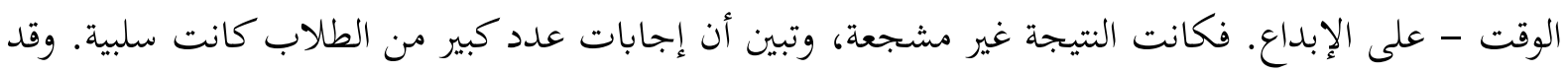

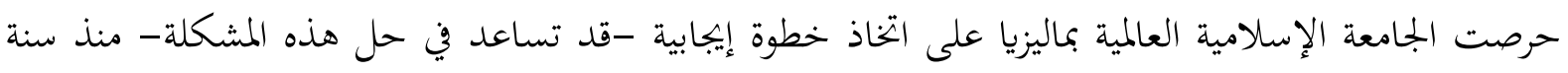

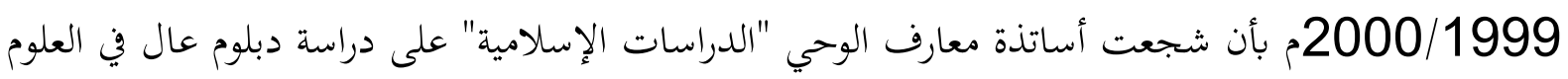

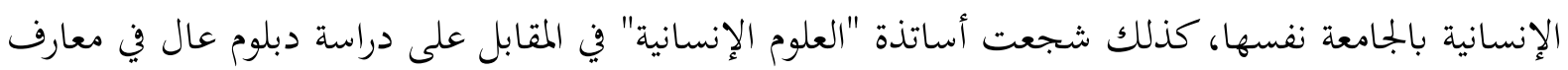

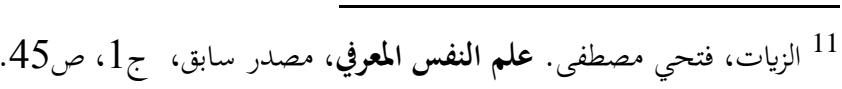

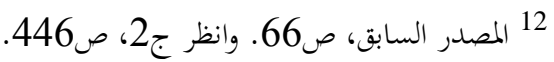


الوحي. ثم تتابع برنامج الدبلوم العالي ليشمل كليات أخرى منها: الطب، والصيدلة في سنة 2004م. ومن بين

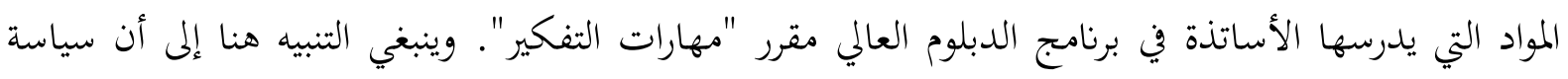
الجامعة التعليمية قامت منذ تأسيسها على أساس الدمج بين العلوم والمعارف والتخصصات. فطلاب التهاب الدراسات

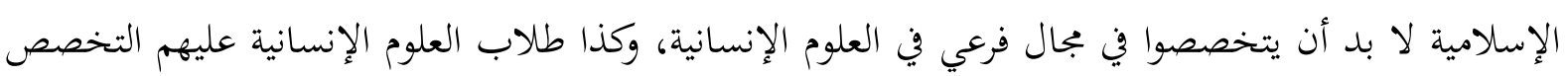

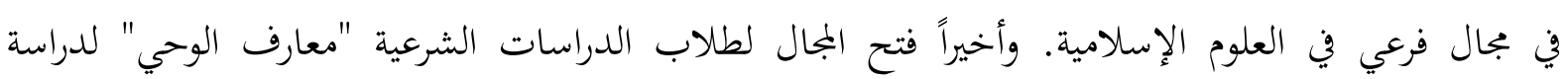

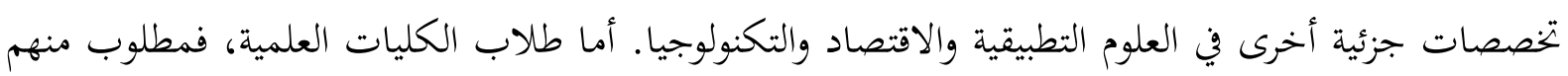

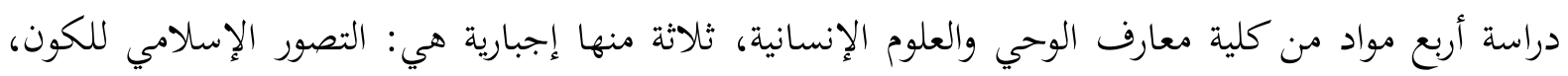

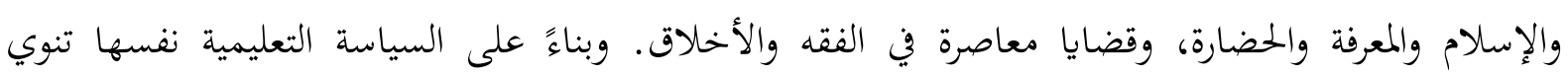

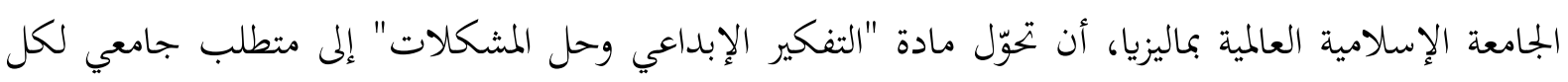

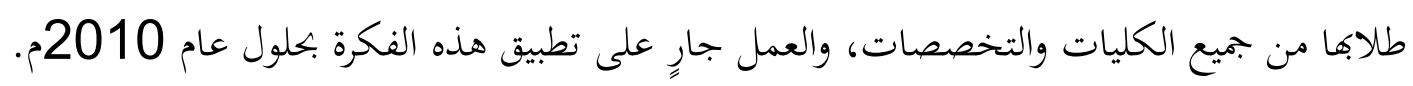

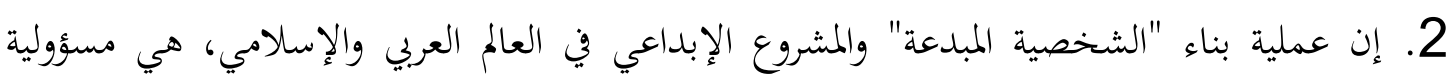

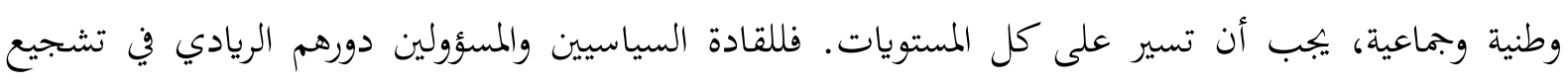

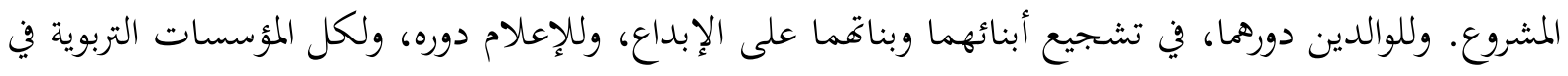

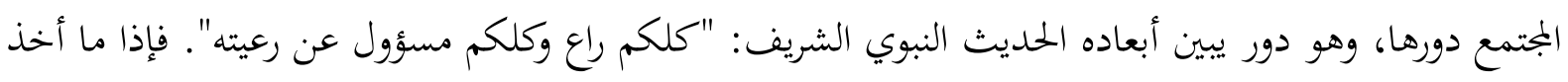

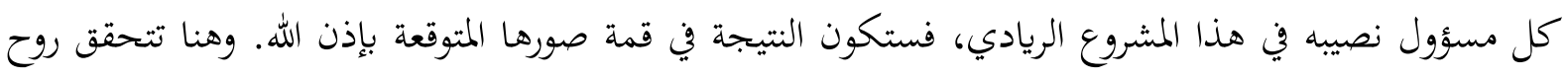

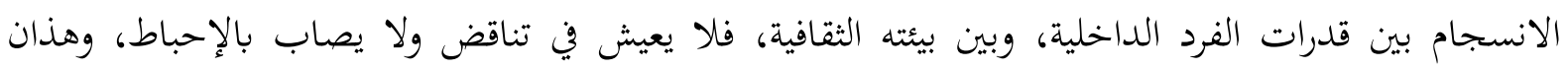

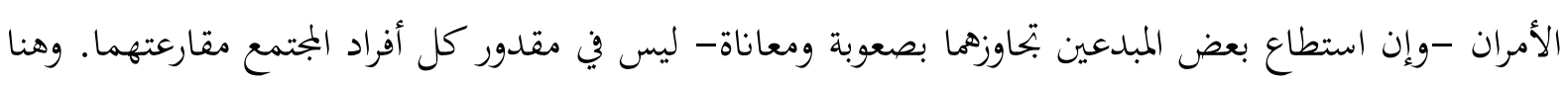

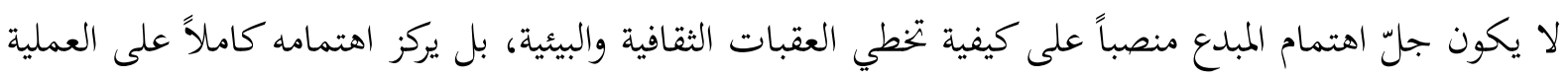

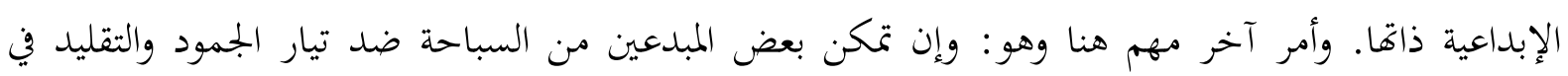

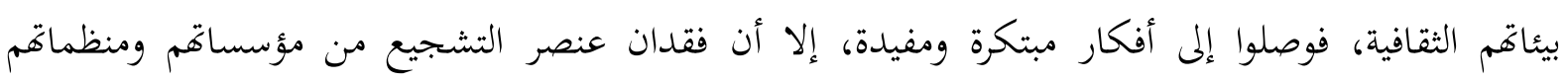

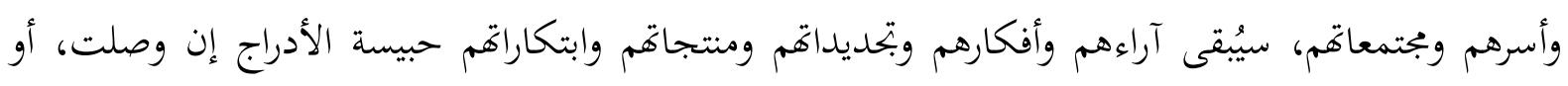

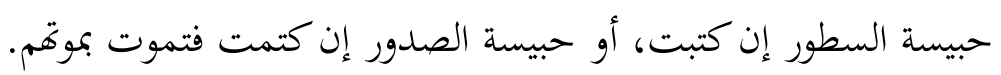

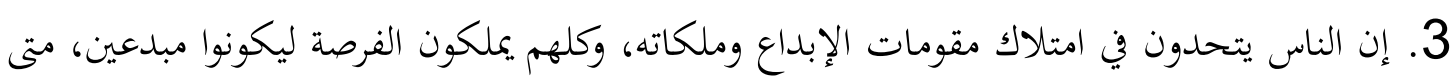

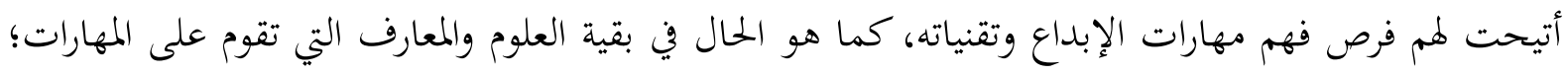

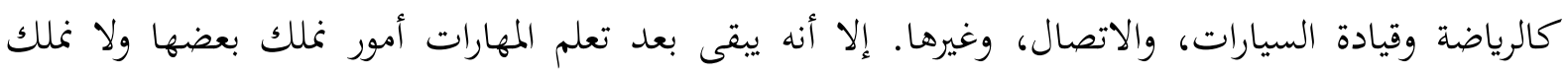

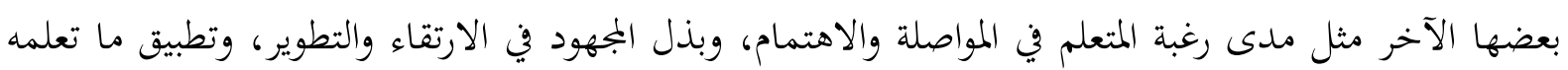

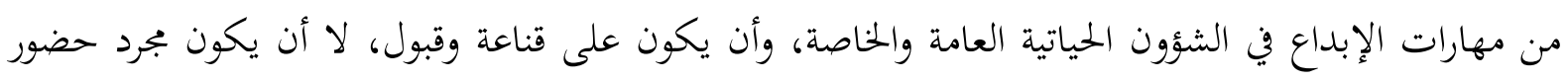

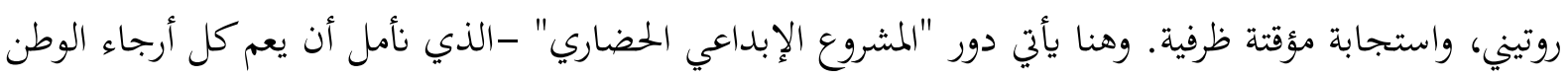

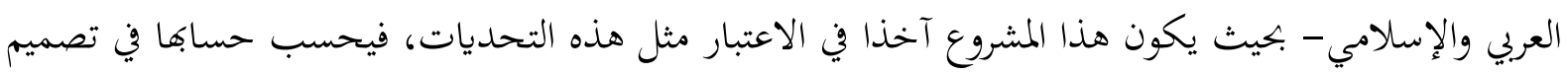


المناهج والمقررات والكتب. وتبرز هنا أهمية ما ذكر في المحاور السابقة من تكامل الأدوار المختلفة لكافة فئات ومؤسسات المجتمع. ولعل من المفيد أن أذكر هنا من واقع بتربة الجامعة الإسلامية العالمية في ماليزيا في تدريس المادة، أنه رغم تغير إدارة الجامعة، إلا أن المشروع بقي على أهميته، وحظي بالاهتمام نفسه. فالحرص على تحقيق رؤية الجامعة وفلسفتها وأداء واجبها، كان هو المحرك والدافع للاستمرار في المشروع والمضي به قدما نحو التحسين المستمر. وكأي عملية تقوم على المهارات والتقنيات، فإن الناس -كما مرّ - يمكنهم جميعا إتقان المهارات من حيث الجملة والعموم، إلا أفم سيتفاوتون في قدراهم وإمكاناةم، وحسب تكوينهم وطاقاقم وبيئاةم، واستعداداتم الفطرية في درجة إعمال هذه المهارات وتطبيقها. وهو ما يشبه أمور الرياضة التي تقوم على تعلم المهارات والتدريب، إلا أن اللاعبين يتفاوتون في مستوى أدائهم، ولا يفوز بالمراتب الأولى إلا أشخاص محددون، ولكن ليس معنى ذلك أن بقية اللاعبين لا يتقنون فن تلك الرياضة، وهذا موضوع نبّه عليه الدكتور دي بونو في مواضع كثيرة من مؤلفاته. 4. ومن الإشكالات المثارة في تدريس هذا المقرر هو تساؤل بعض المتخصصين في هذا المجال أيضاً: هل يمكن قياس وتقويم الإبداع؟ وإذا كان ممكنا فعلى أي أساس يتم ذلك؟ وللتعاطي مع هذا الإشكال لا بد من الإلمام بالجانب التاريخي لتدريس الإبداع. فقد بدأ طرح التساؤل عندما كانت زاوية النظر إلى الإبداع باعتباره موهبة لا يمكن اكتساها ولا يمكن تعلمها أو تعليمها، ولكن يمكن تشجيعها وتحسينها. أما بعد تصميم مهاراته وتقنياته من قبل رواد هذا الفن، وبتريبها وتدريسها ونجاحها الباهر في كثير من دول العالم، فإن هذا التساؤل يصبح أقل إشكالاً. فالتقويم يكون للمحاولة والجهاد المبذول في فهم واستيعاب ثم استعمال المهارات والتقنيات، وهو أمر يمكن قياسه إلى حد كبير ولو بشكل نسبي. 13

خاتمة:

بناءً على ما ناقشته هذه الدراسة وما طرحته من أفكار وقضايا يمكن الوصول إلى نتيجة مهمة ألا وهي: ضرورة قيام مشروع "المجتمع المبدع"، وذلك بضرورة العناية بتدريس مهارات الإبداع في كل مراحل التعليم، بدأ من مرحلة الحضانة في البلاد العربية والإسلامية. ويتطلب هذا المشروع الحضاري إعداد المدربين المهرة ليقوموا بتلك كرك المسؤولية، ولا بـد من إنشاء مؤسسات ومراكز لإعـداد هؤلاء المدربين إعدادا يتكافأ مع دورهم المنشود. كذلك يتطلب أيضاً تغيـير المنـاهج التعليميـة والكتـب المدرسية لتحقيـق هـذا الهـف السـامي، إضـافة إلى حسـن إعـداد المعلمين في المدارس والمؤسسات التعليمية، وإقامة الدورات التدريبية لمم ليتحولوا إلى أساتذة مبدعين. ومن متطلباته أيضاً تواصل الجامعات بالعالم العربي والإسلامي من أجل تفعيل هذا المشروع والاستفادة مـن خبرات الآخرين وبجـاركم. ويجبـ أن يكون لمشروعنا "الإبـداعي الحضـاري" خصوصيته، فينطلق مـن ثوابت 
ثقافتنا وقيمنا. وليس هذا من باب الحجر على الإبداع، بقدر ما هو توجيه له بحيث يكون إبداعاً إيجابياً بناءً، ولكي يتفادى سلبيات الإبداع المنفلت من القيم. وقد بدأت الدراسات في الغرب نفسه -وهو الذي له السبق في هذه التجربة- عن هذا الموضوع، كما في فصل "الجانب المظلم من الإبداع" في دائرة معارف الإبداع 14 وغيره. 15

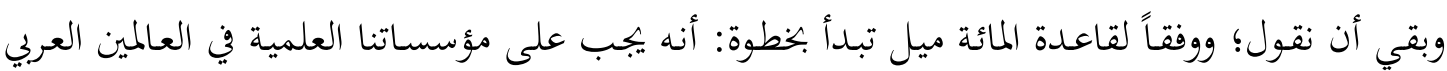
والإسلامي الأخذ بزمام المبادرة لتبني هذا المشروع ونقله إلى أرض الواقع. 